\title{
MINAT, JIWA KEWIRAUSAHAAN DAN PENGETAHUAN UNTUK KESIAPAN BERWIRAUSAHA
}

\author{
Yenny Maya Dora \\ Dosen Fakultas Bisnis Dan Manajemen, Universitas Widyatama Bandung \\ Email: Yenny.maya@widyatama.ac.id
}

Masuk : 15-04-2019, revisi: 09-08-2019, diterima untuk diterbitkan :09-08-2019

\begin{abstract}
ABSTRAK
Menjadikan mahasiswa menjadi seorang wirausaha tidaklah mudah diperlukan beberapa faktor yang menjadi pendorong untuk kesiapan berwirausaha. Oleh karena itu penelitian ini dilakukan untuk mengetahui pengaruh faktor Minat, Jiwa Kewirausahaan dan Pengetahuan terhadap kesiapan berwirausaha mahasiswa menjadi seorang wirausaha di Era Industri 4.0. Penelitian ini dilakukan dengan metode survei, data diperoleh dengan penyebaran kuesioner mahasiswa. Populasi penelitian ini adalah mahasiswa yang telah mengikuti Kuliah Mata Kuliah Kewirausahaan Fakultas Bisnis dan Manajemen Universitas Widyatama. Data dianalisis dengan menggunakan Regresi Linier Berganda. Hasil penelitian ini menunjukkan Faktor Minat berwirausaha, Jiwa Kewirausahaan dan Pengetahuan berpengaruh terhadap Kesiapan berwirausaha seorang mahasiswa.
\end{abstract}

Kata Kunci : Minat, Jiwa Kewirausahaan, Pengetahuan dan Kesiapan Berwirausaha

\section{ABSTRACT}

It is not easy to make students become entrepreneurs. It requires several factors as the drivers for entrepreneurial readiness. Therefore, this study is conducted to determine the influence of factors in Interest, Spirit of Entrepreneurship and Knowledge of entrepreneurial readiness from students to become entrepreneurs in the 4.0 Industrial Era. This study is conducted by survey method. The data is obtained by distributing questionnaires to students. The population is students who have taken the Course of Entrepreneurship at the Faculty of Business and Management at University of Widyatama. Data are analyzed by using Multiple Linear Regression. The results of this study indicate the Factors of Interest in Entrepreneurship, The Spirit of Entrepreneurship and Knowledge have influence on the entrepreneurial readiness of a student.

Keywords: Interest, Spirit of Entrepreneurship, Entrepreneurial Knowledge and Readiness

\section{PENDAHULUAN}

\section{Latar Belakang}

Kenyataan bahwa rendahnya minat dan kesiapan para generasi muda Indonesia untuk berwirausahaan menjadi pemikiran serius semua pihak, baik pemerintah, Dunia Pendidikan, Dunia Industri, maupun masyarakat. Oleh karena itu Gerakan Kewirausahaan Nasional (GKN) yang ditetapkan Presiden Susilo Bambang Yudhoyono pada bulan Februari 2011, bertujuan supaya generasi muda memiliki minat untuk menjadi wirausahawan. Sehingga melalui gerakan ini akan menciptakan lapangan kerja dan mengurangi jumlah pengangguran yang ada dinegara Indonesia. Hal ini juga akan berdampak kepada pembangunan perekonomian negara Indonesia. Karena karier kewirausahaan dapat mendukung kesejahteraan masyarakat yaitu menghasilkan imbalan finansial yang nyata (Agustina \& Sularto, 2011). Sekarang ini, di era Industri 4.0 banyak kesempatan untuk berwirausaha bagi setiap orang yang dapat melihat peluang bisnis yang ada.

Tetapi minat berwirausaha di Indonesia masih sangatlah rendah. Jumlah wirausahawan diIndonesia baru 0,18 persen dari jumlah penduduk, berada jauh di bawah negara lain dibandingkan dengan negara tetangga Malaysia yang sudah 2 persen, Amerika 4 persen, dan Singapura 7 persen. Suatu negara akan maju dan stabil perekonomiannya jika penduduk yang 
menjadi wirausahawan minimal 2 persen dari jumlah penduduk (www.jpnn.com). Menurut McClelland (Kasali, dkk., 2010), salah satu faktor yang membuat sebuah negara menjadi maju, yaitu ketika jumlah wirausaha yang terdapat di negara tersebut minimal $2 \%$ dari populasi penduduknya. Menjadi wirausaha adalah salah satu pilihan untuk memajukan bangsa ini.

Wirausaha merupakan orang yang menciptakan sebuah bisnis yang berhadapan dengan risiko dan ketidakpastian, bertujuan memperoleh profit dan mengalami pertumbuhan dengan cara mengidentifikasi kesempatan dan meman-faatkan sumber daya yang diperlukan.

Berdasarkan Kemdiknas (2010), wirausaha adalah seseorang yang memiliki karakter selalu tidak puas dengan apa yang telah dicapai dan terampilmemanfaatkan peluang dalam mengembangkan usahanya, dengan tujuan untuk meningkatkan kehidupannya.

Kemudian Inpres No. 4 tahun 1995 memberi istilah "wiraswasta/wirausaha" berarti pejuang yang gagah, kekar, berani, dan pantas jadi teladan dalam bidang usaha. Dengan kata lain, wirausaha adalah orang yang mempunyai sifat kewirausahaan seperti; keberanian mengambil risiko, keutamaan, kreativitas, dan keteladanan dalam menangani usaha atau perusahaan dengan berpijak pada kemauan dan kemampuan sendiri.

Minat berwirausaha yang muncul diharapkan akan membentuk kecenderungan membuka usahausaha baru secara mandiri di masa mendatang. Penumbuhan minat wirausaha tidak dapat dilakukan serta merta tanpa adanya pendidikan dan pelatihan yang dapat meng-gerakkan jiwa kewirausahaan seseorang. Oleh karena itu, perubahan pola pikir tentang kewirausahan perlu ditumbuhkan melalui pendidikan formal maupun non formal. Berwirausaha bukan hanya bakat bawaan sejak lahir, namun dapat dipelajari dan diajarkan melalui proses pendidikan formal atau informal. Contohnya, setelah Perang Dunia ke-2 beberapa veteran perang di Amerika belajar berwirausaha, melalui suatu pendidikan atau pelatihan, baik pendidikan/pelatihan singkat maupun pendidikan/pelatihan yang berjenjang. Mereka berwirausaha dengan modal pengetahuan dan fasilitas lainnya. Contoh, Samuel Whalton pendiri Walmart yang kini menjadi retailer terbesar dunia adalah veteran yang memulai usahanya pada usia 47 tahun.

Pengetahuan kewirausahaan mendukung nilai-nilai wirausaha terutama bagi mahasiswa, sehingga diharapkan menumbuhkan jiwa usaha untuk berwirausaha. Oleh karena itu, program pembelajaran kewirausahaan merupakan salah satu strategi yang penting untuk mengubah kecenderungan seseorang sebagai job seeker menjadi job creator diwaktu mendatang. Dengan perubahan lingkungan bisnis global menuju era digital atau Revolusi Industri 4.0, perusahaan dan organisasi nirlaba di Indonesia perlu beradaptasi dan menyelaraskan strategi dengan modal insani organisasinya (Watson, 2017).

Hasil observasi awal pada minat berwirausaha yang peneliti dapat, meliputi (1) Minat Berwirausaha yang pada mahasiswa Fakultas Bisnis dan Manajemen masih rendah, (2) produk yang dihasilkan oleh para mahasiswa masih sebagian besar meniru produk yang sudah ada, dan (3) mahasiswa juga belum paham produk yang memiliki market share, sehingga mengakibatkan produk atau jasa yang dijual mahasiswa tidak laku.

Modal yang paling utama untuk menjadi seorang wirausaha adalah minat, semangat, berani dan pantang menyerah. Minat berwirausaha, Jiwa Kewirausahaan dan ditambah dengan pengetahuan tentang wirausaha yang mereka dapat di Perguruan Tinggi nantinya akan berpengaruh terhadap kesiapan mahasiswa tersebut yang mana pada awalnya mereka memilih menjadi pencari kerja 
berubah menjadi pencipta lapangan pekerjaan. Karena jika mahasiswa memiliki minat, jiwa dan pengetahuan berwirausha yang tinggi maka mereka tidak akan kehabisan ide dalam menghasilkan sesuatu yang baru dan lebih menarik serta inovatif. Untuk menangkap peluang yang muncul di era industri 4.0 dimana peran manusia sudah tergeserkan oleh teknologi.

Berdasarkan beberapa paparan sebelumnya penelitian ini menganggap bahwa ketiga faktor tersebut dapat mempengaruhi kesiapan berwirausaha. Maka dari itu, perlunya untuk peningkatan mengenai kesiapan berwirausaha di kalangan mahasiswa. Kesiapan berwirausaha diharapkan tertanam dalam setiap diri mahasiswa. Hal ini dirasa penting dikarenakan kesiapan merupakan prediktor yang tepat untuk menilai perilaku seseorang dalam berwirausaha. Pentingnya penelitian yang berkaitan dengan minat berwirausaha, Jiwa Kewirausahaan dan Pengetahuan yaitu untuk mengetahui pengaruh variabel tersebut terhadap kesiapan mahasiswa dalam berwirausaha di era revolusi industri 4.0, sehingga produk atau jasa yang dihasilkan mahasiswa khususnya mahasiswa Fakultas Bisnis Dan Manajemen sesuai harapan para konsumen di era revolusi industri 4.0.

\section{Minat}

Minat dapat didefinisikan sebagai sesuatu yang membangkitkan perhatian pada suatu hal. Minat mengindikasikan apa yang diinginkan atau dilakukan orang atau apa yang mereka senangi. Seseorang yang berminat pada suatu hal, maka segala tindakan atau apa yang dilakukan akan mengarahkannya pada minatnya tersebut. Menurut Shaleh (2004) bahwa minat adalah suatu kecenderungan untuk memberikan perhatian dan bertindak terhadap orang, aktivitas atau situasi yang menjadi objek dari minat tersebut yang disertai dengan perasaan senang dari dalam hati.

Menurut Djamarah (2011), minat adalah kecenderungan yang menetap untuk memperhatikan dan mengenang beberapa aktivitas. Sedangkan menurut Bernadetha (2014), minat adalah suatu keadaan motivasi atau satu set motivasi yang menuntun tingkah laku menuju sasaran tertentu. Sehingga Minat berwirausaha merupakan keinginan, keterkaitan, serta kesediaan untuk bekerja keras atau berusaha memenuhi kebutuhan hidupnya tanpa merasa takut dengan risiko dari kegagalan yang dialami. Mahasiswa harus memiliki minat yang tinggi terhadap kesiapan berwirausaha. Karena minat merupakan faktor pendorong yang menjadikan seseorang lebih giat bekerja, sehingga mampu melihat dan menangkap setiap peluang yang ada dengan mengoptimalkan potensi yang ada.

\section{Jiwa Kewirausahaan}

Menurut Kuratko (2003), Jiwa kewirausahaan meliputi kepribadian yang memiliki tindakan kreatif sebagai nilai, gemar berusaha, tegar dalam berbagai tantangan, percaya diri, memiliki self determination atau locus of control, berkemampuan mengelola risiko, perubahan dipandang sebagai peluang, toleransi terhadap banyaknya pilihan, inisiatif dan memiliki need for achievement, perfeksionis, berpandangan luas, menganggap waktu sangat berharga serta memiliki motivasi yang kuat, dan karakter itu telah menginternalisasi sebagai nilai-nilai yang diyakini benar. Menurut Hartanti (2008), Jiwa kewirausahaan merupakan nyawa kehidupan dalam kewirausahaan yang pada prinsipnya merupakan sikap dan perilaku kewirausahaan dengan ditunjukkan melalui sifat, karakter, dan watak seseorang yang memiliki kemauan dalam mewujudkan gagasan inovatif kedalam dunia nyata secara kreatif. Dari uraian di atas jiwa kewirausahaan berpengaruh pada kesiapan berwirausaha mahasiswa. 


\section{Pengetahuan}

Menurut Suriasumantri (2005), Pengetahuan adalah segenap apa yang diketahui mengenai suatu objek tertentu termasuk didalamnya ilmu, agama dan seni, khasanah kekayaan mental yang secara langsung maupun tidak langsung turut memprakarsai kehidupan manusia.

Sedangkan menurut Nitisusastro (2010), Pengetahuan adalah membekali diri dengan pengertian dan pemahaman serta kompetensi tentang seluk beluk bidang yang akan digeluti.

Dan menurut Nurbaya (2012), Pengetahuan berwirausaha adalah ilmu, seni maupun perilaku, sifat, ciri dan watak seseorang yang mewujudkan gagasan inovatif kedalam dunia nyata secara kreatif. Untuk memulai bisnis, pengetahuan akademik dan pengetahuan kewirausahaan sangat diperlukan. Dengan pengetahuan yang dimiliki seseorang dapat berekreasi dan berinovasi, karena dengan pengetahuan yang dimiliki mahasiswa akan memiliki kemampuan untuk mengembangkan pemikirannya dalam berbisnis. Menurut Suryana (2013:88) menyatakan bahwa pengetahuan yang dimiliki oleh seseorang sangat diperlukan terutama untuk :

1. Menghasilkan produk dan jasa;

2. Menghasilkan nilai tambah baru;

3. Merintis usaha baru;

4. Melakukan proses/ teknik baru;

5. Mengembangkan organisasi baru

Sehingga berbekal pengetahuan mahasiswa akan lebih siap untuk berwirausaha di era industri 4.0 .

\section{Kesiapan Berwirausaha}

Menurut Slameto (2003), Kesiapan adalah keseluruhan kondisi seseorang yang membuatnya siap untuk memberikan respon atau jawaban di dalam cara tertentu terhadap suatu situasi. Menurut Dalyono (2005), Kesiapan adalah kemampuan yang cukup baik fisik maupun mental. Menurut Nitisusatro (2009), Kesiapan berwirausaha adalah kesiapan diri pribadi seseorang yang ketika memasuki dunia usaha. Sedangkan menurut Nurbaya (2012), Kesiapan berwirausaha adalah kemauan, keinginan dan kemampuan untuk berwirausaha dalam hal ini tergantung pada tingkat kematangan, pengalaman masa lalu, keadaan mental dan emosi seseorang. Sedangkan menurut Irsyada dkk (2018), Kesiapan berwirausaha adalah suatu kondisi dimana seseorang merasa telah memiliki bekal dalam berwirausaha yang membuatnya siap dalam menghadapi situasi baik itu bersifat negatif maupun positif dalam berwirausaha. Dimana bekal yang dimiliki meliputi minat dan jiwa serta pengetahuan berwirausaha.

\section{Rumusan Masalah}

Dari uraian di atas maka dapat disusun rumusan masalah untuk penelitian ini adalah sebagai berikut :

1. Bagaimana pengaruh minat terhadap kesiapan berwirausaha?

2. Bagaimana pengaruh Jiwa Kewirausahaan terhadap kesiapan berwirausaha?

3. Bagaimana pengaruh Pengetahuan terhadap kesiapan berwirausaha?

4. Bagaimana Minat, Jiwa Kewirausahaan, dan Pengetahuan berpengaruh pada Kesiapan Berwirausaha?

Sedangkan kerangka pemikiran untuk penelitian ini adalah sebagai berikut : 


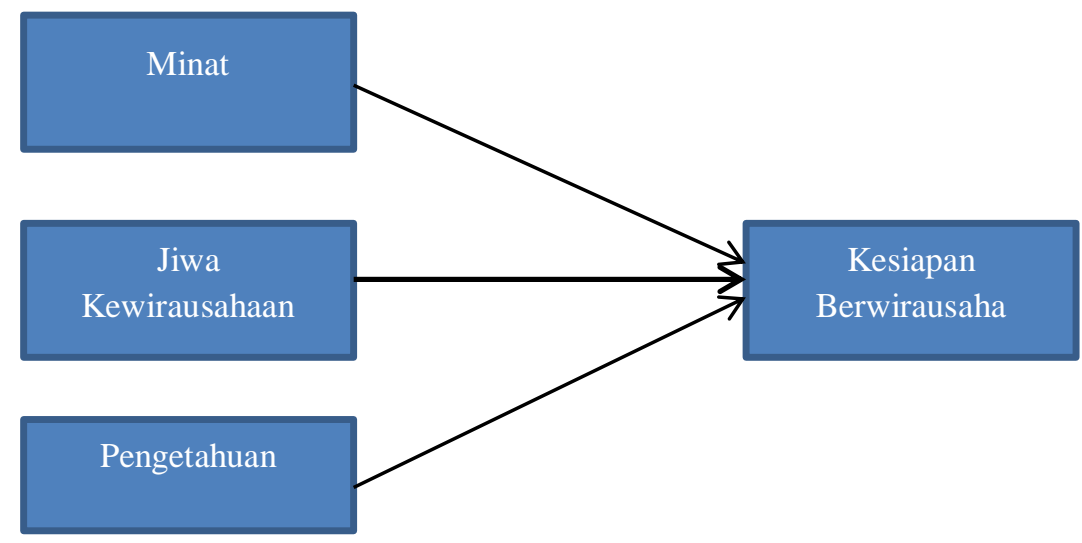

\section{Gambar 1 : Kerangka Pemikiran}

Berdasarkan rumusan masalah dan kerangka pemikiran maka hipotesis untuk penelitian ini adalah :

1. Minat berpengaruh terhadap Kesiapan Berwirausaha.

2. Jiwa Kewirausahaan berpengaruh terhadap Kesiapan Berwirausaha.

3. Pengetahuan Berpengaruh Terhadap Kesiapan Berwirausaha.

4. Minat, Jiwa Kewirausahaan dan Pengetahuan berpengaruh terhadap Kesiapan Berwirausahaan.

\section{METODE PENELITIAN}

Metode penelitian ini adalah survei dengan pendekatan analisis kuantitatif. Tujuannya adalah untuk menguji pengaruh Minat, Jiwa Berwirausaha, Pengetahuan terhadap Kesiapan berwirausaha mahasiswa. Variabel-variabel pada penelitian ini terdiri variabel bebas dan variabel terikat. Variabel bebas adalah variabel yang nilainya mempengaruhi nilai variabel lain atau variabel yang menyebabkan timbulnya perubahan atau berubahnya variabel terikat. (Sugiyono, 2017; 39). Adapun variabel-variabel bebas yang digunakan pada penelitian ini adalah Minat (X1), Jiwa Kewirausahaan (X2) dan Pengetahuan (X3). Sedangkan Variabel terikat adalah variabel yang dipengaruhi atau menjadi akibat karena adanya variabel bebas. (Sugiyono, 2017;39). Dimana variabel terikat penelitian ini adalah Kesiapan Berwirausaha (Y). Metode pengumpulan data menggunakan instrumen kuesioner dengan responden sebanyak 100 mahasiswa. Metode yang digunakan adalah simple random sampling (acak) dengan tingkat kesalahan 5\%. Data diolah dan dianalisis dengan menggunakan bantuan software SPSS for Windows seri 21.0.

\section{HASIL DAN PEMBAHASAN \\ Deskripsi Responden.}

Responden penelitian ini adalah mahasiswa Prodi Manajemen S1 Fakultas Bisnis Dan Manajemen Universitas Widyatama yang sudah mengambil mata kuliah Kewirausahaan 1 dan sedang mengambil kuliah mata kuliah Kewirausahan 2. Jumlah sampel penelitian ini 100 mahasiswa yang terdiri dari 60 mahasiswa pria dan 40 mahasiswa wanita.

\section{Hasil Uji Instrumen}

Uji validitas dengan menggunakan software SPSS for Windows seri 21.0, diperoleh hasil uji bahwa seluruh item pertanyaan adalah valid karena masing-masing item nilai corrected ItemTotal Correla-tion memiliki nilai lebih besar dari standar minimum 0,3. Hasil uji validasi dapat dilihat pada Tabel 1,2, 3 dan 4. Dari tabel 1, 2, 3 dan 4 diketahui bahwa semua item-item 
pertanyaan kuesioner valid karena nilai corrected Item-Total Correlation dari masing-masing item memiliki nilai yang lebih besar daripada standar minimum 0,165

\section{Uji Validitas}

Hasil uji validasi untuk variabel Minat, Jiwa Kewirausahaan, Pengetahuan dan Kesiapan berwirausaha dapat dilihat pada Tabel 1,2, 3 dan 4 berikut ini. Dari tabel 1, 2, 3 dan 4 diketahui bahwa semua item-item pertanyaan kuesioner valid karena nilai $r$ hitung dari masing-masing item memiliki nilai yang lebih besar daripada $\mathrm{r}$ tabel.

Tabel 1. Uji Validasi Variabel Minat

Sumber : Data diolah, 2019

\begin{tabular}{|c|c|c|c|}
\hline & $\boldsymbol{r h i t u n g}$ & $\boldsymbol{r}$ tabel & Kesimpulan \\
\hline Item 1 & 0,561 & 0,3 & Valid \\
\hline Item 2 & 0,486 & 0,3 & Valid \\
\hline Item 3 & 0,334 & 0,3 & Valid \\
\hline Item 4 & 0,705 & 0,3 & Valid \\
\hline Item 5 & 0,635 & 0,3 & Valid \\
\hline
\end{tabular}

Tabel 2. Uji Validasi Variabel Jiwa Kewirausahaan

Sumber : Data diolah, 2019

\begin{tabular}{|c|c|c|c|}
\hline & r hitung & r tabel & Kesimpulan \\
\hline Item 1 & 0,562 & 0,3 & Valid \\
\hline Item 2 & 0,484 & 0,3 & Valid \\
\hline Item 3 & 0,442 & 0,3 & Valid \\
\hline Item 4 & 0,707 & 0,3 & Valid \\
\hline Item 5 & 0,636 & 0,3 & Valid \\
\hline
\end{tabular}

Tabel 3. Uji Validasi Variabel Pengetahuan

Sumber : Data diolah, 2019

\begin{tabular}{|c|c|c|c|}
\hline & r hitung & r tabel & Kesimpulan \\
\hline Item 1 & 0,569 & 0,3 & Valid \\
\hline Item 2 & 0,485 & 0,3 & Valid \\
\hline Item 3 & 0,531 & 0,3 & Valid \\
\hline Item 4 & 0,705 & 0,3 & Valid \\
\hline
\end{tabular}

Tabel 4. Uji Validasi Variabel Kesiapan berwirausaha

Sumber : Data diolah, 2019

\begin{tabular}{|c|c|c|c|}
\hline & r hitung & r tabel & Kesimpulan \\
\hline Item 1 & 0,571 & 0,3 & Valid \\
\hline Item 2 & 0,490 & 0,3 & Valid \\
\hline Item 3 & 0,511 & 0,3 & Valid \\
\hline Item 4 & 0,708 & 0,3 & Valid \\
\hline Item 5 & 0,640 & 0,3 & Valid \\
\hline
\end{tabular}

Dari tabel 1,2, 3 dan 4 diketahui bahwa semua item-item pertanyaan kuesioner valid karena nilai $r$ hitung dari masing-masing item memiliki nilai yang lebih besar daripada $r$ tabel.

\section{Uji Reliabilitas}

Hasil Uji realibilitas kuesioner Minat, Jiwa Kewirausahaan, Pengetahuan, dan Kesiapan Berwirausaha ditunjukkan pada Tabel 5 sebagai berikut : 
Tabel 5. Rekapitulasi Uji Realiabilitas Sumber : Data diolah, 2019

\begin{tabular}{|l|c|c|c|}
\hline \multicolumn{1}{|c|}{ Variabel } & Alpha & RKritis & Kesimpulan \\
\hline Minat & 0,749 & 0,60 & Reliabel \\
\hline Jiwa Kewirausahaan & 0,725 & 0,60 & Reliabel \\
\hline Pengetahuan & 0,720 & 0,60 & Reliabel \\
\hline Kesiapan Berwirausaha & 0,731 & 0,60 & Reliabel \\
\hline
\end{tabular}

Tabel 5 menunjukkan nilai Cronbach's Alpha 0,749 > 0,600. Artinya bahwa kuesioner Minat dalam penelitian ini adalah reliabel. Tabel 5 juga menunjukkan nilai Cronbach's Alpha 0,725 > 0,600. Artinya bahwa kuesioner Jiwa Kewirausahaan dalam penelitian ini adalah reliabel. Tabel 5 juga menunjukkan nilai Cronbach's Alpha 0,720>0,600. Artinya, bahwa kuesioner Pengetahuan dalam penelitian ini adalah reliabel. Dan Tabel 5 menunjukkan nilai Cronbach's Alpha 0,731 > 0,600. Artinya, bahwa kuesioner Kesiapan Berwirausaha dalam penelitian ini adalah reliabel. Sehingga kuesioner tersebut dapat digunakan dalam pengumpulan data penelitian ini.

\section{Hasil Uji Hipotesis}

\section{Hasil Uji t}

Uji t digunakan untuk mengetahui pengaruh secara parsial yaitu Minat Berwiarausaha (X1), Jiwa Kewirausahaan (X2), dan Pengetahuan (X3), terhadap minat berwirausaha (Y). Hasil uji parsial (uji t) dapat dilihat pada tabel 6 berikut ini :

Tabel 6. Hasil Uji Parsial (Uji t)

Sumber : Data diolah, 2019

\begin{tabular}{|l|c|c|c|c|c|}
\hline \multicolumn{1}{|c|}{ Model } & \multicolumn{2}{|c|}{$\begin{array}{c}\text { Unstandardized } \\
\text { Coefficients }\end{array}$} & $\begin{array}{c}\text { Standardized } \\
\text { Coefficients }\end{array}$ & i & sig \\
\hline & B & std Error & Beta & & \\
\hline (Constant) & 7,251 & 2,776 & & 2,612 & 0,11 \\
Minat Berwirausaha & 0,433 & 0.130 & 0,329 & 4,338 & 0,001 \\
Jiwa Kewirausahaan & 0,385 & 0,167 & 0,325 & 3,303 & 0,005 \\
Pengetahuan & 0,435 & 0,129 & 0,330 & 4,498 & 0,000 \\
\hline
\end{tabular}

Berdasarkan tabel 6 di atas dapat diuraikan sebagai berikut :

1. Pengaruh Minat Berwirausaha terhadap Kesiapan Berwirausaha.

Dari tabel di atas didapat nilai t hitung sebesar 4,338 dengan Nilai Sig sebesar 0,001, sehingga variabel Minat Berwirausaha berpengaruh signifikan terhadap Kesiapan Berwirausaha.

2. Pengaruh Jiwa Kewirausahaan terhadap Kesiapan Berwirausaha.

Dari tabel di atas diadapat nilai t hitung sebesar 3,303 dengan nilai Sig sebesar 0,005, sehingga variabel Jiwa Kewirausahaan berpengarug signifikan terhadap Kesiapan Berwirausaha.

3. Pengaruh Pengetahuan terhadap Kesiapan Berwirausaha.

Dari tabel di atas didapat nilai t hitung sebesar 4,498 dengan Nilai Sig sebesar 0,000, sehingga variabel Pengetahuan berpengaruh signifikan terhadap Keseiapan Berwirausaha.

\section{Koefisien Korelasi Berganda}

Hasil perhitungan untuk Koefisien korelasi berganda dapat dilihat pada Tabel 7. Dari Tabel 7 dapat diketahui seberapa baiknya model analisis secara keseluruhan, yaitu bagaimana variabel bebas mampu memprediksikan satu variabel terikat. 
Tabel 7. Model Summary

Sumber : Data diolah, 2019

\begin{tabular}{|c|c|c|c|c|}
\hline Model & $\boldsymbol{R}$ & $\boldsymbol{R}$ Square & $\begin{array}{c}\text { Adjusted } \boldsymbol{R} \\
\text { Square }\end{array}$ & $\begin{array}{c}\text { Std Error of } \\
\text { The Estimate }\end{array}$ \\
\hline 1 & 0,824 & 0,679 & 0,676 & 6.16826 \\
\hline
\end{tabular}

Dari tabel 7 didapat hasil $R$ Square sebesar 0,679 ini berarti ketiga variabel bebas memiliki kontribusi yang kuat kepada variabel terikat. Adapun kontribusi ketiga variabel tersebut (Variabel Minat, Variabel Jiwa Kewirausahaan dan Variabel Pengetahuan) sebesar 67,9\% terhadap variabel Kesiapan Berwirausaha. Sisanya sebesar 32,1\% dipengaruhi oleh faktor lain yang tidak diteliti.

\section{Hasil Uji F}

Berdasarkan hasil output analisis regresi, dapat diketahui nilai $F$ seperti pada Tabel 8 berikut ini:

Tabel 8. Uji $F$ Anova

Sumber : Data diolah, 2019

\begin{tabular}{|ll|c|c|c|c|c|}
\hline \multicolumn{1}{|l|}{ Model } & Sum of Squares & Df & Mean Square & Nilai $\boldsymbol{F}$ & Signifikansi \\
\hline \multirow{2}{*}{ Regression } & 168,158 & 3 & 65,826 & 32,289 & 0,000 \\
& Residu & 196,873 & 95 & 1,964 & & \\
& Total & 365,031 & 98 & & & \\
\hline
\end{tabular}

Dari hasil di atas Nilai $F$ sebesar 32,289 dengan Sig $F$ sebesar 0,000 $<0,05$ ini menunjukkan bahwa model ini dapat digunakan untuk mengatahui Kesiapan Berwirausaha mahasiswa. Dan dari hasil ini diketahui bahwa Minat, Jiwa Kewirausahaan dan Pengetahuan berpengaruh signifikan terhadap Kesiapan Berwirausaha.

\section{Pembahasan}

Dari hasil olah data didapat ketiga variabel yaitu, Variabel Minat, Jiwa Kewirausahaan dan Pengetahuan berpengaruh signifikan terhadap Kesiapan Berwirausaha. Berdasarkan hasil tersebut dapat dipastikan bahwa minat untuk mahasiswa berwirausaha berpengaruh terhadap Kesiapan Berwirausaha. Penelitian ini sejalan dengan penelitian yang dilakukan oleh Irsyada, dkk. (2018) yang menyatakan bahwa minat berpengaruh terhadap kesiapan Berwirausaha mahasiswa. Sementara itu Jiwa Kewirausahaan akan mendorong minat mahasiswa untuk berwirausaha. Sehingga dengan dorongan Jiwa Kewirausahaan menghasilkan minat mahasiswa untuk berwirausaha. Dan berbekal pengetahuan yang dimiliki oleh mahasiswa akan membuat mahasiswa lebih siap lagi untuk berwirausaha. Hasil penelitian ini membuktikan bahwa pengetahuan sangat mendukung untuk Kesiapan Berwirausaha. Hasil penelitian ini sejalan dengan hasil penelitian yang dilakukan Davinci dan Maryati (2011) yang menyatakan bahwa pengetahuan berpengaruh terhadap Kesiapan Berwirausaha. Mahasiswa yang telah mendapat pembelajaran dan pengetahuan mengenai kewirausahaan akan lebih siap untuk memulai berwirausaha.

\section{KESIMPULAN DAN SARAN}

\section{Kesimpulan}

Berdasarkan hasil pengolahan data dan pembahasan maka dapat dibuat kesimpulan bahwa :

1. Minat berpengaruh secara signifikan terhadap Kesiapan Berwirausaha Mahasiswa. Sehingga dapat dikatakan bahwa Minat mahasiswa berwirausaha akan membuat mahasiswa siap melakukan wirausaha di Era Industri 4.0. 
2. Jiwa Kewirausahaan secara signifikan berpengaruh pada Kesiapan Berwirausaha. Sehingga berbekal Jiwa Kewirausahaan mahasiswa akan siap berwirausaha di Era Industri 4.0.

3. Pengetahuan berpengaruh signifikan terhadap Kesiapan Berwirausaha mahasiswa. Dengan ditambah bekal pengetahuan mengenai wirausaha mahasiswa akan lebih siap berwirausaha. Karena tanpa pengetahuan yang cukup mahasiswa akan mengalami kesulitan dalam menjalankan wirausaha di Era Industri 4.0.

4. Minat, Jiwa Kewirausahaan dan Pengetahuan secara bersama-sama berpengaruh signifikan terhadap Kesiapan Berwirausaha. Ini berarti bahwa dengan adanya minat dan didukung oleh Jiwa Kewirausahaan serta dibekali pengetahuan tentang wirausaha maka mahasiswa akan benar-benar siap melakukan wirausaha di Era 4.0.

\section{Saran}

Dari hasil penelitian yang telah dilakukan maka peneliti menyarankan kepada pihak universitas untuk melakukan beberapa hal berikut :

1. Menambahkan di dalam materi pembelajaran untuk mewajibkan mahasiswa mengikuti pelatihan-pelatihan atau workshop-workshop yang tujuannya menambah pengetahuan mahasiswa untuk berwirausaha.

2. Melibatkan mahasiswa dalam acara bazar atau pameran yang dilakukan oleh pemerintah.

3. Melakukan pendampingan pada mahasiswa dalam menjalankan bisnisnya.

\section{Ucapan Terima Kasih}

Penulis mengucapkan terima kasih kepada Dekan Fakultas Bisnis Dan Manajemen, dan Ketua Program Studi Manajemen S1, dan Dosen Kewirausahaan 2 serta Mahasiswa-mahasiswa Program Studi Manajemen S1 yang sedang mengikuti kuliah mata kuliah Kewirausahaan 2 yang telah membantu penulis dalam melakukan penelitian ini.

\section{REFERENSI}

Abdul Rahman Shaleh. 2004. Psikologi Suatu Pengantar dalam Perspektif Islam. Jakarta: Kencana.

Agustina, C., \& Sularto, L. (2011). Intensi kewirausahaan mahasiswa (Studi Perbandingan antara Fakultas Ekonomi dan Fakultas Komputer. Procceding PESAT (Psikologi Ekonomi Sastra Arsitektur \& Sipil, (hal. 63-64).

Badan Pusat Statistik. (2018). Keadaan Ketenagakerjaan Indonesia Agustus 2018., dari www. Bps.go.id.

Bernadeta Wahyu Asri. (2014). Pengaruh Faktor Internal dan Faktor Eksternal Terhadap Minat Berwirausaha Siswa SMK Ardjuna 1 Malang. Skripsi Jurusan Manajemen-

Fakultas Ekonomi. Universitas Malang

Dalyono. 2005. Psikologi Pendidikan. Jakarta: Rineka Cipta.

Davinci dan Maryati, 2011. “ Kesiapan Berwirausaha Mahasiswa Teknik Mesin Universitas Muhammadiah Yogyakarta Ditinjau dari Pengetahuan Kewirausahaan, Dukungan Keluarga, Soft Skill, dan Prestasi Belajar.” JBTI., Vol II No. 1.

Djamarah, Bahri, 2011. Psikologi Pendidikan. Jakarta. Rineka Cipta

Hartanti. 2008. "Manajemen pengembangan kewirausahaan (entrepreneurship) siswa SMK 4 Yogyakara." Universitas Negeri Yogyakarta.

Irsyahda, dkk, 2018, " Kontribusi Minat Berwirausaha dan Self Efficacy terhadap Kesiapan Berwirausaha di Era Revolusi Industri 4.0 Mahasiswa Teknik Informatika se-Malang." Jurnal Pendidikan., Vol 3. No. 7.

Kasali, Rhenald, 2010, Wirausaha Muda Mandiri. Jakarta: Gramedia Pustaka Utama 
Kuratko, D. F. 2003. "Kuratko, D. F. 2003. Entrepreneurship education: Emerging trends and challenger for the 21st century." Coleman Foundation White paper series for the US Association of small business and entrepreneurship.

Niode, I. Y., \& Mopangga, H. (2014). Penguatan Produksi dan Manajemen Usaha Stik Jagung Ikan Gorontalo. Kajian Ekonomi Dan Bisnis OIKOS - NOMOS, 7 (September).

Nitisusastro, Mulyadi, 2009. Kewirausahaan dan Manajemen Usaha Kecil. Bandung. PT. Alfabeta.

Nurbaya, Siti dan Moerdiyanto.(2012). Faktor-Faktor Yang Mempengaruhi Kesiapan Berwirausaha Siswa Kelas XII SMKN Barabai Kabupaten Hulu Sungai Tengah Kalimantan Selatan. Artikel Siti-Murdi, hlm. 3

Slameto. 2003. Belajar dan Faktor-faktor yang Mempengaruhinya. Jakarta: Rineka Cipta.

Sugiyono. 2017. Metode Penelitian Kuantitatif, Kualitatif, dan R\&D. Bandung. PT. Alfabeta.

Suryana. (2013). Kewirausahaan, Pedoman Praktis: Kiat dan Proses Menuju Sukses. Edisi Empat. Jakarta:Salemba Empat.

Wilson, F., \& Kickul, J. (2007). Gender, Entrepreneurial Self-Efficacy, and Entrepreneurial Career Intentions: Implications for Entrepreneurship Education. Education, (617), 387407.

DIKTI. (2017). Panduan Program Wirausaha Mahasiswa. www.dikti.go.id. 